\title{
Morphometric Analysis of Bite Mark Patterns Caused by Domestic Dogs (Canis lupus familiaris) Using Dental Wax Registers
}

\author{
Análisis de Patrones de Huellas de Mordedura Producidos por Perros Domésticos \\ (Canis lupus familiaris) Utilizando Registros en Cera Dental
}

V. A. Toledo-González ${ }^{1,2,3}$; F. E. Ortega-Ojeda ${ }^{1,2}$; G. M. Fonseca ${ }^{4}$; C. García-Ruiz ${ }^{1,2}$ \& P. Pérez-Lloret ${ }^{3}$

\begin{abstract}
TOLEdo-GonZÁlez, V. A.; ORTEGA-OJEDA, F. E.; FONSECA, G. M.; GARCÍA-RUIZ, C. \& PÉREZ-LLORET, P. Morphometric analysis of bite mark patterns caused by domestic dogs (Canis lupus familiaris) using dental wax registers. Int. J. Morphol., 37(3):885-893, 2019.
\end{abstract}

SUMMARY: Dog bites are a known public health problem involving physical, mental and emotional traumas. From a forensic point of view, it has been stated that their morphological characters, and the intercanine and interincisive measurements, could allow a taxonomic and specific identification of the implicated animal. The aim of this study was to differentiate and identify the biological profile of a potential aggressor dog by analysing eight morphometric bite patterns belonging to three different dog breeds. The data obtained were analyzed following three categories: a) breeds; b) sexes among breeds; and c) sex within breed. Significant differences were detected among the variables ( $\mathrm{p} \leq 0.05)$, but only the maximum maxillary intercanines width (MaxCW) allowed a breed differentiation. The other variables allowed a differentiation between two breeds or one breed over the others. The principal components analysis (PCA) allowed visualizing the degree of dispersion and relationship among the scores. It showed three well-defined and separated breed groups, and different degrees of dispersion within and among breeds. The most important variable for such a differentiation was MaxCW. When considering sex among breeds for males, it showed a statistically significant difference, but only the diastema located between the third left mandibular, incisive and the left mandibular canine (C-I-ManL) allowed breed differentiation. For females, only MaxCW allowed a differentiation among breeds. The multivariate analysis permitted with a $95 \%$ confidence interval, a breed and sex differentiation. Besides, the PCA models allowed classifying, identifying, separating and graphically showing the relationship among the variables. This made it possible to differentiate between breeds and sexes. Due to the large range of dog breeds around the world, this multivariate analysis could also help determining the dog's weight and size, narrowing down towards an approximate number of offending dogs, focussing on a certain kind of dog breed, and pinpointing any suspect dog.

KEY WORDS: Dog bite marks; Forensic science; Forensic odontology; Forensic veterinary.

\section{INTRODUCTION}

Injuries caused by animals are a worldwide public health problem, that keeps rising (O'Brien et al., 2015) with important economic losses, high morbidity and mortality (Skavic et al., 2015). Both wildlife and domestic animals may cause these injuries (Skavic et al.). The most common animal related injuries are caused by dogs $(85-90 \%$ of the total number of injuries caused by mammals) (Abuabara, 2006; Tsokos et al., 2007), followed by cats (5-10\%), and rodents (2-3\%) (Muñoz Leyva, 2011; Chhabra et al., 2013). Canine bites are a known public health problem (Alabi et al., 2014; Karbeyaz \& Ayranci, 2014; O’Brien et al.) combined with physical, mental, and emotional traumas
(Chhabra et al.). The most vulnerable people are the elderly and small children (Karbeyaz \& Ayranci), but it may involve victims at any age, especially when more than one dog is implicated (Byard, 2016). Studies indicate that males are affected by dog bites more often than females in a sex ratio of $2: 1$, and in $90 \%$ of cases the aggressor dog belongs to the victim or it is known by him/her (Rothe et al., 2015).

The morphology of dog bite marks on the human skin depends on the shape and nature of the teeth present in the animal dentition (Byard). The injuries are punctiform "Vshaped" wounds and the lesions often develop irregular and

\footnotetext{
${ }^{1}$ Department of Analytical Chemistry, Physical Chemistry and Chemical Engineering, and Edificio Polivalente de Química, University of Alcalá, Madrid, Spain.

${ }^{2}$ University Institute of Research in Police Sciences (IUICP), University of Alcalá, Madrid, Spain.

${ }^{3}$ Department of Animal Anatomy and Embryology. Faculty of Veterinary. Universidad Complutense of Madrid, Madrid, Spain.

${ }^{4}$ Centro de Investigación en Odontología Legal y Forense (CIO), Facultad de Odontología, Universidad de La Frontera, Temuco, Chile.
} 
furrowed margins (Colard et al., 2015; Fonseca et al., 2015), including superficial abrasions (30-43\%), lacerations (31$45 \%$ ), and others (13-34\%) (Chhabra et al.).

It has been established that these morphological characters (intercanine and interincisive measurements), could allow identifying both the animal species involved in the attack and the aggressor dog following the protocols proposed by Colard et al. and Fonseca et al.

In nonfatal bite cases or in the presence of witnesses, the forensic investigation often aims at identifying the unknown offender animal. Nevertheless, the finding of remains, with alleged animal intervention in outdoor scenes can make research more complex in certain cases, where a legitimate or criminal litigation exists (Fonseca et al.).

In a previous article, bite patterns of three dog breeds (German shepherd, Dalmatian, and Deutscher boxer) were compared using dental wax (Toledo et al., 2012) according to their skull shape (Onar, 1999). The main results showed that only the maximum distance between the upper canines was statistically significant $(\mathrm{p} \leq 0.05)$, allowing the breed identification. Likewise, a high correlation was found among the measurements taken in plaster casts and bite patterns on wax. This led to the conclusion that such plaster casts could be used to compare the suspect dog dentition with the injuries recovered in the attack scene, and to identify the aggressor animal (Toledo et al.). Nonetheless, these morphometric studies need to be supplemented by morphological studies (Tedeschi-Oliveira et al., 2011). Both morphological and morphometric methods are useful complementary tools to identify a potentially aggressive dog (Toledo et al.).

With the goal of facilitating the biological profile identification of a potential offending dog, this study analysed four maxillary and four mandibular measurements, as source of variations, within and among breeds and for sex: maximum canines width, maximum incisive width, and canine- third incisive distance.

\section{MATERIAL AND METHOD}

The animal set for the experiments consisted of three groups of ten dogs each, categorized by breed: 1) German shepherd (weight for males: $30-40 \mathrm{~kg}$, and females: $25-32$ $\mathrm{kg}$ ); 2) Dalmatian (weight for males: $25-27 \mathrm{~kg}$, and females: 24-26 kg); and 3) Deutscher boxer (weight for males: 30-35 $\mathrm{kg}$, and females: $25-31 \mathrm{~kg}$ ). Each group comprised ten breed dogs (five females and five males), with definitive, comple- te, healthy, and non-treated dentition. Because the dogs belonged to a hatchery, the use of chemicals (e.g., tranquilisers, etc.) was not necessary during the sampling and caring of the subjects. The methodology used for obtaining the primary data was approved by the Ethics Committee of the University of Chile (FIV:12101401.9102.007, 2010).

The bites were recorded on $1 \times 70 \times 140 \mathrm{~mm}$ sheets of dental pink wax that were used to cover both sides of an expandable polyurethane block of $2 \mathrm{~cm}$ height. This enabled to obtain simultaneously the bite patterns of the mandibular and maxillary teeth during the biting process. The researcher placed the full wax block inside the dog's mouth while the dog's owner pressed the maxilla and mandible against the block until achieving a maximal occlusion). It is important to indicate that this study consider the concept "bite marks" based in the American Board of Forensic Odontology (ABFO) definition: "A physical alteration or representative pattern recorded in a medium caused by the contact of the teeth of a human or animal" (American Board of Forensic Odontology, 2018).

For the morphometric study, the bite registrations were scanned using an Epson Perfection V 500 Photo flatbed scanner (Epson Corp, Japan), and saved in JPEG format with a 600 dpi resolution, and 1:1 real scale. The variables considered in the study were: 1) maximum maxillary intercanines width (MaxCW);2) maximum mandibular intercanines width (ManCW);3) maximum maxillary between third incisives width (MaxIW); 4) maximum mandibular between third incisives width (ManIW); 5) diastema located between the third right maxillary incisive and the right maxillary canine (C-I-MaxR); 6) diastema located between the third left maxillary incisive and the left maxillary canine (C-I-MaxL); 7) diastema located between the third right mandibular incisive and the right mandibular canine (C-I-ManR); and 8) diastema located between the third left mandibular incisive and the left mandibular canine (C-I-ManL).

The measurements were made with a Traceable digital calliper (Control Company, ISO 17025, USA) and registered in millimetres ( $\mathrm{mm}$ ). For the $\mathrm{MaxCW}$, ManCW, MaxIW, and ManIW, the maximum external distances between the outer edges of every bite pattern were considered. However, for the other measurements, the minimum internal distances between the edges were used.

The observations (animals) were analyzed considering three categories: a) breeds, b) sexes among breeds, and c) sex within breed. For the statistical analysis, various ANOVA with factorial design and multiple 
comparisons were used within the IBM SPSS v22 (IBMCorp Armonk. USA) software. A $95 \%$ confidence interval was considered $(p \leq 0.05)$. The results were presented as mean and standard deviation (SD).

Furthermore, principal components analysis (PCA) and orthogonal projection to latent structures and discriminant analysis (OPLS-DA) was used to interpret to what extent a breed and/or sex differs from each other, and to identify the critical variables that allow such differentiation. The multivariate analysis was performed with SIMCA (Sartorius Stedim Biotech, France) (Dago Morales et al., 2008). The data was previously centered and scaled (Pareto), and the software was set to calculate the boundaries with $95 \%$ probability (Dago Morales et al.) to compensate for any magnitude unbalance and/or variance that could exist. This enabled to eliminate any weight due to the variables or observations magnitude.

\section{RESULTS}

Table I shows the results achieved throughout the analysis of variance considering breeds. Although significant differences were detected among the variables $(p<0.05)$, only MaxCW allowed a breed differentiation. The other variables allowed a differentiation between two breeds or one breed over the others. Only the observations of the German shepherd and Dalmatian breeds were different from one another for all variables.

The scores plot is commonly drawn in terms of the principal components (PC) as PC1, PC2, PC3, etc. However, the second largest chemometrics community draws those plots with the t-nomenclature, that is, $t[1], t[2], t[3]$, etc. Accordingly, the three initial scores in Figure 1A, t[1], t[2], and $\mathrm{t}[3]$, explained near 66,16 , and $7.6 \%$ of the model,

Table I. Averages and standard deviation of the different measurements considering breed as a source of variation.

\begin{tabular}{|c|c|c|c|c|c|c|c|c|c|}
\hline \multicolumn{2}{|c|}{ Breed/variable } & $\begin{array}{l}\text { MaxCW } \\
(*)\end{array}$ & $\begin{array}{l}\text { ManCW } \\
(++)\end{array}$ & $\begin{array}{l}\text { MaxIW } \\
(+)\end{array}$ & $\begin{array}{l}\text { ManIW } \\
(+)\end{array}$ & $\begin{array}{l}\text { C-I } \\
\text { MaxR } \\
(++) \\
\end{array}$ & $\begin{array}{l}\text { C-I } \\
\text { MaxL } \\
\quad(++)\end{array}$ & $\begin{array}{l}\text { C-I } \\
\text { ManR } \\
(+) \\
\end{array}$ & $\begin{array}{l}\text { C-I } \\
\text { ManL } \\
\quad(+)\end{array}$ \\
\hline \multirow{2}{*}{ German shepherd } & Mean & $52.3 \mathrm{a}$ & $46.8 \quad \mathrm{a}$ & $40.1 \mathrm{a}$ & 29.9 a & $9.0 \mathrm{a}$ & $8.3 \mathrm{a}$ & $3.8 \mathrm{a}$ & $3.9 \mathrm{a}$ \\
\hline & SD & 8.2 & 2.9 & 2.59 & 2.0 & 0.9 & 1 & 0.85 & 0.9 \\
\hline \multirow[t]{2}{*}{ Dalmatian } & Mean & $47.0 \mathrm{~b}$ & $40.4 \mathrm{~b}$ & $34.4 \mathrm{~b}$ & $25.9 \mathrm{~b}$ & $6.8 \mathrm{~b}$ & $6.7 \mathrm{~b}$ & $1.9 \mathrm{~b}$ & $2.0 \mathrm{~b}$ \\
\hline & $\mathrm{SD}$ & 3.5 & 3.3 & 3.04 & 1.4 & 1 & 0.8 & 0.47 & 0.7 \\
\hline \multirow[t]{3}{*}{ Deutscher boxer } & Mean & $58.3 \mathrm{c}$ & $43.7 \mathrm{ab}$ & $35.5 \mathrm{~b}$ & $26.5 \mathrm{~b}$ & $7.9 \mathrm{ab}$ & $7.3 \mathrm{ab}$ & $3.4 \mathrm{a}$ & $3.4 \mathrm{a}$ \\
\hline & $\mathrm{SD}$ & 5.5 & 6.1 & 3.5 & 3.2 & 1.5 & 1.2 & 1.0 & 0.9 \\
\hline & & $\mathrm{p}=0.000$ & $\mathrm{p}=0.010$ & $\mathrm{p}=0.001$ & $\mathrm{p}=0.001$ & $\mathrm{p}=0.001$ & $\mathrm{p}=0.004$ & $\mathrm{p}=0.000$ & $\mathrm{p}=0.000$ \\
\hline
\end{tabular}

The different letters, by column, show statistically significant differences $(\mathrm{p} \leq 0.05)$. (*) Differences among all breeds. (+) Differences one breed over others. (++) Differences one breed from another.
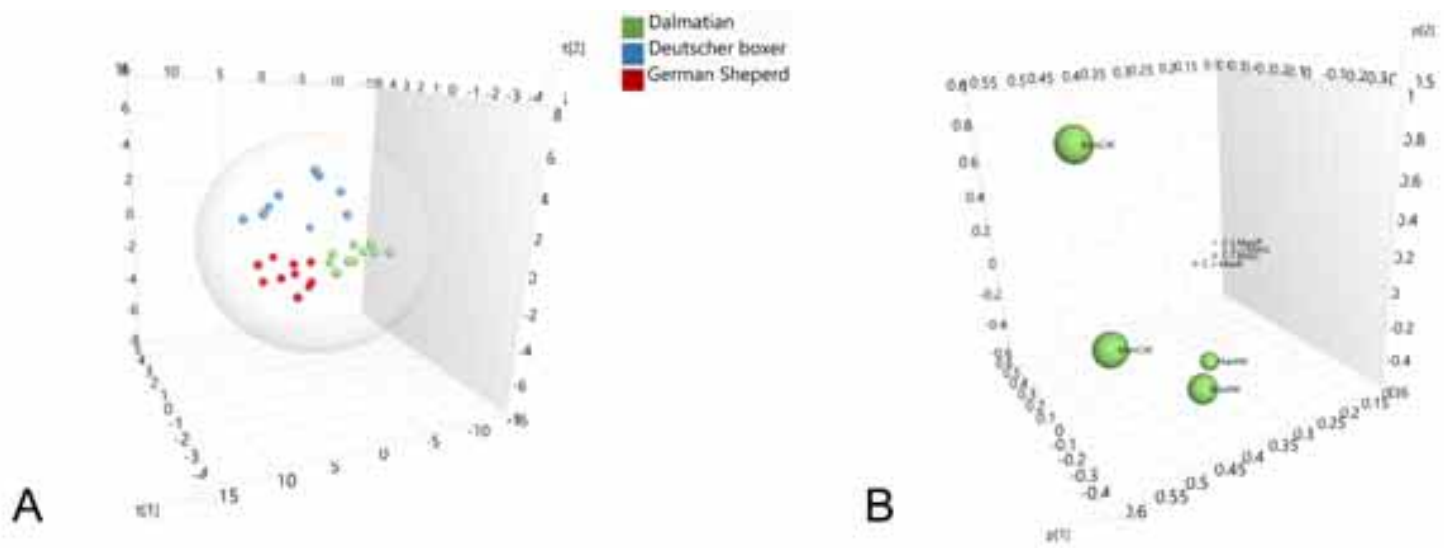

Fig. 1A: 3D scores scatter plot showing the distribution, dispersion and relation of the scores within and among breeds. The scores, $\mathrm{t}[1]$, $\mathrm{t}[2]$, and $\mathrm{t}[3]$, explained near 66,16 , and $7.6 \%$, respectively. B: 3D loadings scatter plot corresponding to the contributions and space relationships of the variables differentiating the breeds in Figure 1A. The loadings, p[1], p[2], and p[3], explained about 66, 16, and 7.6 $\%$, respectively. 
respectively. Thus, the whole model explained about $(89.6$ $\%)$ of the variance among breeds. The PCA allowed visualizing the degree of dispersion and relation among the scores (within and among breeds). It showed three welldefined and separated breeds groups, and different degrees of dispersion within and among breeds.

Figures $1 \mathrm{~A}$ and $1 \mathrm{~B}$ show the $3 \mathrm{D}$ plots of scores and loadings scatter respectively. The loadings plot describes and visualizes the space relationship among the variables with respect to the samples. Furthermore, it helps determining which variables are responsible for the differences among breeds. The loadings, $\mathrm{p}[1], \mathrm{p}[2]$, and $\mathrm{p}[3]$, correspond in location to their respective scores in Figure 1A, and thus, explained near 66,16 , and $7.6 \%$, respectively.

Regarding $\mathrm{p}$ [1], all variables were positive (from left to right in Figure 1B), clearly stating that all contributed to distinguish between breeds. Nonetheless, the most important variable for such a differentiation was MaxCW and (ManCW). There is a direct correlation among them, which implies that if one rises, the others may follow. After those variables, (MaxIW) followed (ManIW) (Fig. 1B).
Table II shows the ANOVA among breeds considering sex as a source of variation. When considering sex among breeds for males, it showed a statistically significant difference on MaxCW, ManIW, CI-MaxR, C-IMaxL, C-I-ManR, and C-I-ManL. However, only C-IManL allowed the breed differentiation. The other variables allowed only a differentiation between two breeds or one breed over the others. For females, there was a statistically significant difference on MaxCW, ManCW, MaxIW, ManIW, C-I-MaxR, C-I-MaxL, and C-I-ManR. Nonetheless, only MaxCW allowed a differentiation among breeds (Table III).

Figure $2 \mathrm{~A}$ represents the $3 \mathrm{D}$ scores scatter plot showing the distribution and relationship of males within and among breeds. The three initial scores $\mathrm{t}[1]$, $\mathrm{t}[2]$, and t[3], explained almost 65.7, 13.3, and $11.9 \%$, respectively, and the whole model explained about $90.9 \%$ of the variance. The PCA shows that there are three separate groups of males according to breed, from which, Deutscher boxer presented the largest dispersion. Furthermore, MaxCW, and ManCW had the largest weights to differentiate males among breeds (Fig. 2B).

Table II. Averages and standard deviation considering sex as a source of variation.

\begin{tabular}{|c|c|c|c|c|c|c|c|c|c|}
\hline \multicolumn{2}{|c|}{ Males Breed /Variable } & $\begin{array}{c}\text { MaxCW } \\
(++)\end{array}$ & $\begin{array}{c}\text { ManCW } \\
(-)\end{array}$ & $\begin{array}{c}\text { MAxIW } \\
(-)\end{array}$ & $\begin{array}{c}\text { ManIW } \\
(++)\end{array}$ & $\begin{array}{c}\text { C-I } \\
\text { MaxR } \\
(+)\end{array}$ & $\begin{array}{c}\text { C-I } \\
\text { MaxL } \\
(++)\end{array}$ & $\begin{array}{c}\text { C-I } \\
\text { ManR } \\
(+)\end{array}$ & $\begin{array}{c}\text { C-I } \\
\text { ManL } \\
(*)\end{array}$ \\
\hline $\begin{array}{l}\text { German } \\
\text { Shepherd }\end{array}$ & Mean SD & $\begin{array}{c}54.2 \mathrm{ab} \\
2.8\end{array}$ & $\begin{array}{r}48.2 \mathrm{a} \\
3\end{array}$ & $\begin{array}{c}41.6 \mathrm{a} \\
1.9\end{array}$ & $\begin{array}{c}30.8 \mathrm{a} \\
2.44\end{array}$ & $\begin{array}{c}9.2 \mathrm{a} \\
1.2\end{array}$ & $\begin{array}{c}8.4 \mathrm{a} \\
1.4\end{array}$ & $\begin{array}{c}4.5 \mathrm{a} \\
0.52\end{array}$ & $\begin{array}{c}4.7 \mathrm{a} \\
0.3\end{array}$ \\
\hline Dalmatian & Mean SD & $49.9 \mathrm{~b}$ & $42.7 \mathrm{a}$ & $36.0 \mathrm{a}$ & $26.7 \mathrm{~b}$ & $7.0 \mathrm{~b}$ & $6.8 \mathrm{~b}$ & $1.8 \mathrm{~b}$ & $1.7 \mathrm{~b}$ \\
\hline \multirow{2}{*}{$\begin{array}{l}\text { Deutscher } \\
\text { boxer }\end{array}$} & Mean SD & 59.7 a & $46.7 \mathrm{a}$ & $36.4 \mathrm{a}$ & $29.0 \mathrm{ab}$ & $9.2 \mathrm{a}$ & $8.3 \mathrm{ab}$ & $3.8 \mathrm{a}$ & $3.6 \mathrm{c}$ \\
\hline & & $\begin{array}{r}7.0 \\
\mathrm{p}=0.016\end{array}$ & $\begin{array}{r}7.2 \\
\mathrm{p}=0.216\end{array}$ & $\begin{array}{c}4.8 \\
p=0.420\end{array}$ & $\begin{array}{c}2.26 \\
\mathrm{p}=0.029\end{array}$ & $\begin{array}{c}0.8 \\
\mathrm{p}=0.0\end{array}$ & $\begin{array}{c}0.73 \\
\mathrm{p}=0.035\end{array}$ & $\begin{array}{c}1.1 \\
\mathrm{p}=0.000\end{array}$ & $\begin{array}{c}0.9 \\
\mathrm{p}=0.0\end{array}$ \\
\hline
\end{tabular}

Different letters, by column, show statistically significant differences ( $\mathrm{p} \leq 0.05)$; * Differences among all breeds; (+): Differences one breed over others; $(++)$ : Differences one breed from another; (-): Without difference among breeds.

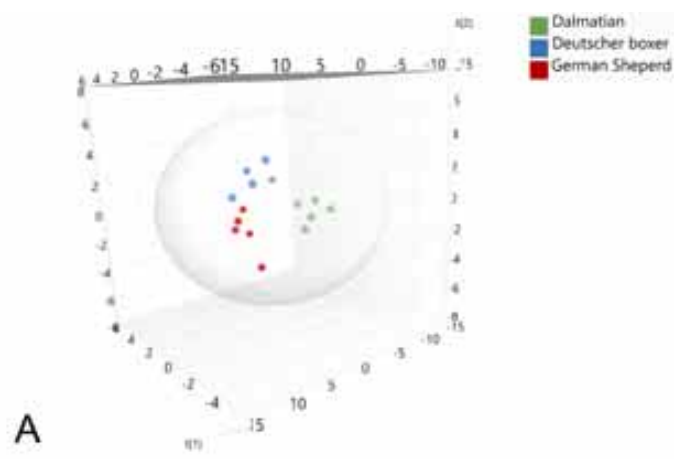

B

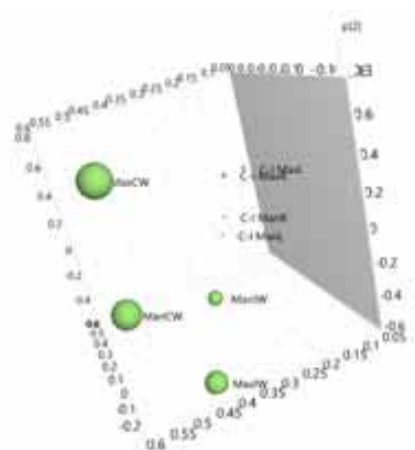

Fig. 2A: 3D scores scatter plot showing the distribution and relationships of males within and among breeds. The scores t[1], t[2], and t[3], explained near 65.7, 13.3, and 11.9\%, respectively. B: 3D loadings scatter plot showing the variables contributions for the differentiation of males among breeds and its space relationships. The loadings, $\mathrm{p}[1], \mathrm{p}[2]$, and $\mathrm{p}[3]$, explained about $65.7,13.3$, and $11.9 \%$, respectively. 
TOLEDO-GONZÁLEZ, V. A.; ORTEGA-OJEDA, F. E.; FONSECA, G. M.; GARCÍA-RUIZ, C. \& PÉREZ-LLORET, P. Morphometric analysis of bite mark patterns caused by domestic dogs (Canis lupus familiaris) using dental wax registers. Int. J. Morphol., 37(3):885-893, 2019.

Table III. Average and standard deviation values considering sex as a source of variation.

\begin{tabular}{|c|c|c|c|c|c|c|c|c|c|}
\hline \multicolumn{2}{|c|}{$\begin{array}{l}\text { Females } \\
\text { Breed /Variable }\end{array}$} & $\begin{array}{c}\mathrm{MaxCW} \\
(*)\end{array}$ & $\begin{array}{c}\text { ManCW } \\
(+)\end{array}$ & $\begin{array}{c}\text { MAxIW } \\
(+)\end{array}$ & $\begin{array}{c}\text { ManIW } \\
(+)\end{array}$ & $\begin{array}{c}\text { C-I } \\
\text { MaxR } \\
(+)\end{array}$ & $\begin{array}{c}\text { C-I } \\
\text { MaxL } \\
(+)\end{array}$ & $\begin{array}{c}\text { C-I } \\
\text { ManR } \\
(+)\end{array}$ & $\begin{array}{c}\text { C-I } \\
\text { ManL } \\
(-)\end{array}$ \\
\hline German & Mean & $50.5 \quad \mathrm{a}$ & $45.4 \mathrm{a}$ & $38.6 \mathrm{a}$ & $28.9 \mathrm{a}$ & $8.8 \mathrm{a}$ & $8.2 \mathrm{a}$ & $3.2 \mathrm{a}$ & $3.2 \mathrm{a}$ \\
\hline Shepherd & SD & 2.6 & 2.3 & 2.5 & 1.1 & 0.6 & 0.4 & 0.5 & 0.5 \\
\hline Dalmatian & Mean & $44.1 \mathrm{~b}$ & $38.0 \mathrm{~b}$ & $32.7 \mathrm{~b}$ & $25.0 \mathrm{~b}$ & $6.6 \mathrm{~b}$ & $6.6 \mathrm{~b}$ & $2.0 \mathrm{~b}$ & 2.3 \\
\hline & SD & 1.8 & 1.2 & 2.3 & 1.0 & 1.1 & 1.0 & 0.6 & 0.9 \\
\hline Deutscher & Mean & $57.0 \mathrm{c}$ & $40.7 \quad b$ & $34.6 \mathrm{~b}$ & $24.0 \mathrm{~b}$ & $6.6 \mathrm{~b}$ & $6.4 \mathrm{~b}$ & $3.1 \mathrm{~b}$ & $3.3 \mathrm{a}$ \\
\hline boxer & SD & $\begin{array}{l}3.8 \\
p=0.000\end{array}$ & $\begin{array}{l}3.1 \\
p=0.001\end{array}$ & $\begin{array}{l}1.6 \\
p=0.003\end{array}$ & $\begin{array}{l}1.3 \\
p=0.000\end{array}$ & $\begin{array}{l}0.7 \\
p=0.001\end{array}$ & $\begin{array}{l}0.7 \\
p=0.002\end{array}$ & $\begin{array}{l}0.87 \\
\mathrm{p}=0.038\end{array}$ & $\begin{array}{l}1.0 \\
p=0.181\end{array}$ \\
\hline
\end{tabular}

Different letters, by column, show statistically significant differences $(\mathrm{p} \leq 0.05) ; *$ Difference among all breeds; $(+)$ : Difference one breed over others; (++): Differentiate one breed another; (-): Without difference among breeds.
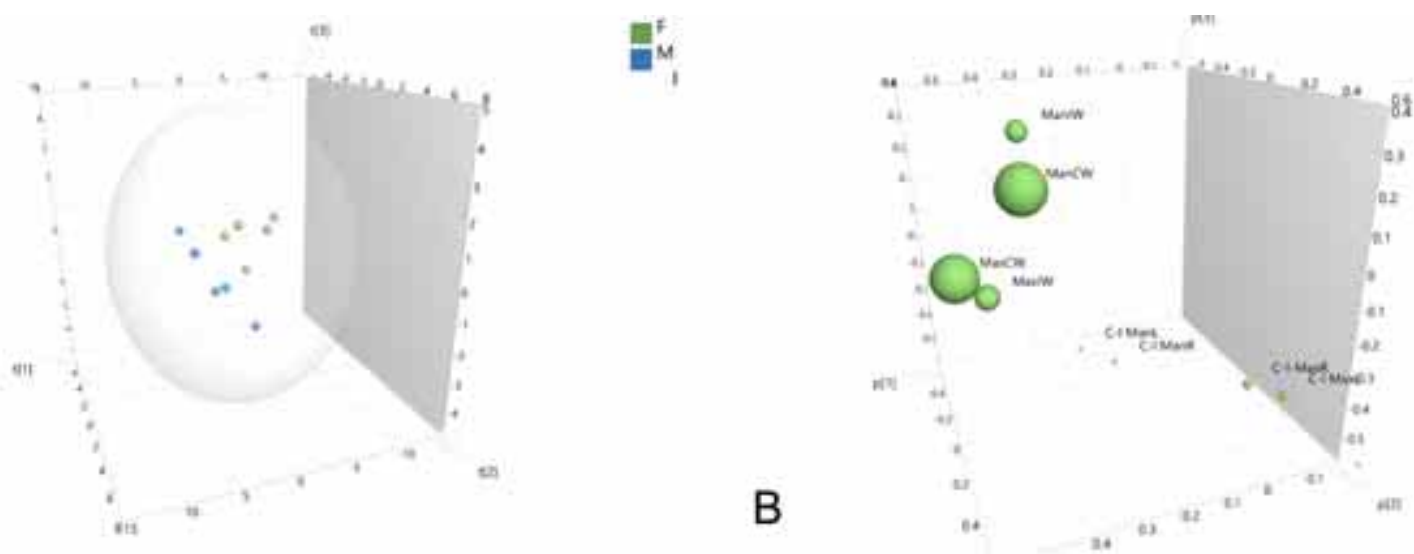

Fig. 3A: 3D Score scatter plot showing the dispersion and relationship of the scores between sexes (green for female and blue for male) within the German shepherd breed. The scores $\mathrm{t}[1], \mathrm{t}[2]$, and $\mathrm{t}[3]$ explained almost $60.7,18.8$, and 9.8 \%, respectively. B: 3D loading scatter plot indicating the contributions of each variable to the variability between sexes within the German Shepherd breed and its spatial relationship. The loading $\mathrm{p}[1], \mathrm{p}$ [2], and $\mathrm{p}$ [3] explained almost 60.7, 18.8, and 9.8 \%, respectively.

The corresponding PCA for females $(94.4 \%$ explained variance, figure not shown) showed three separate groups according to breed. The Deutscher boxer presented the largest dispersion, while MaxCW and ManCW had the largest weights for differentiating females among breeds.

Table IV shows the statistical parameters (mean and standard deviation) of the variables with statistically significant differences for the sex class, within breeds. Regarding the German shepherd breed, the MaxCW, C-IManR, and C-I-ManL variables presented statistically significant differences between males and females. Considering the Dalmatian breed, MaxCW, ManCW, and ManIW, presented statistically significant differences. Finally, the variables that showed statistically significant differences for the Deutscher boxer were ManIW, C-I-MaxR, and C-I-MaxL.
The PCA showed that there were two separate groups (sexes) within breeds, although not all the variables showed statistically significant differences among them (Table IV).

Figure $3 \mathrm{~A}$ represents the $3 \mathrm{D}$ score scatter plot showing the relationship between sexes within the German shepherd breed (the figures for other breeds are not shown). The three initial scores $\mathrm{t}[1], \mathrm{t}[2]$, and $\mathrm{t}[3]$, explained almost $60.7,18.8$, and $9.8 \%$, respectively. The model explained over $89 \%$ of the variability between sexes (within breeds). In addition, Figure 3B represents the 3D loading scatter plot indicating the contributions of each variable to the variability between sexes within the German shepherd breed and its spatial relationship. The loadings $\mathrm{p}$ [1], $\mathrm{p}$ [2], and $\mathrm{p}$ [3], explained about $60.7,18.8$, and $9.8 \%$, respectively. The figure showed that the MaxCW and $\mathrm{ManCW}$ variables were the most important for the sex differentiation. 
TOLEDO-GONZÁLEZ, V. A.; ORTEGA-OJEDA, F. E.; FONSECA, G. M.; GARCÍA-RUIZ, C. \& PÉREZ-LLORET, P. Morphometric analysis of bite mark patterns caused by domestic dogs (Canis lupus familiaris) using dental wax registers. Int. J. Morphol., 37(3):885-893, 2019.

Table IV. Mean and standard deviation values of the variables with statistically significant differences (p£ 0.05) between sexes for the German shepherd, Dalmatian, and Deutscher boxer breeds.

\begin{tabular}{lcccc}
\hline \multicolumn{2}{c}{ Breed/variable } & MaxCW & C-I-ManR & C-I-ManL \\
\hline German shepherd & (M) & $54.1 \pm 2.8 \mathrm{a}$ & $4.5 \pm 0.5 \mathrm{a}$ & $4.7 \pm 0.3 \mathrm{a}$ \\
& (F) & $50.5 \pm 2.6 \mathrm{~b}$ & $3.2 \pm 0.5 \mathrm{~b}$ & $3.2 \pm 0.5 \mathrm{~b}$ \\
& & $\mathrm{p}=0.066$ & $\mathrm{p}=0.003$ & $\mathrm{p}=0.001$ \\
Dalmatian & MaxCW & ManCW & ManIW \\
& $(\mathrm{M})$ & $49.9 \pm 1.8 \mathrm{a}$ & $42.7 \pm 3.0 \mathrm{a}$ & $26.7 \pm 1.3 \mathrm{a}$ \\
& (F) & $44.1 \pm 1.8 \mathrm{~b}$ & $38.0 \pm 1.1 \mathrm{~b}$ & $25.0 \pm 1.0 \mathrm{~b}$ \\
& & $\mathrm{p}=0.001$ & $\mathrm{p}=0.013$ & $\mathrm{p}=0.047$ \\
Deutscher boxer & ManIW & $\mathbf{C}-\mathbf{I}-\mathbf{M a x R}$ & $\mathbf{C}-\mathbf{I}-\mathbf{M a x L}$ \\
& $(\mathrm{M})$ & $29.0 \pm 2.3 \mathrm{a}$ & $9.2 \pm 0.8 \mathrm{a}$ & $8.3 \pm 0.7 \mathrm{a}$ \\
& (F) & $24.0 \pm 1.3 \mathrm{~b}$ & $6.6 \pm 0.7 \mathrm{~b}$ & $6.4 \pm 0.7 \mathrm{~b}$ \\
& & $\mathrm{p}=0.003$ & $\mathrm{p}=0.000$ & $\mathrm{p}=0.002$ \\
\hline
\end{tabular}

Different letters, by column, show statistically significant differences (p£ 0.05); M: male; F: female.

\section{DISCUSSION}

Only MaxCW allowed a breed differentiation and the other variables only allowed a differentiation between two breeds or one breed over the others. Therefore, our findings suggest that those variables rendered good results and thus they may be considered for such differentiation studies.

Some authors stated that the inter-canine width is not a reliable variable for identification due to its high level of false positives (Toledo et al.; Tarvadi et al., 2016). Other authors also indicate that this measurement was not good for differentiating dog breeds (Tedeschi-Oliveira et al.). This is a problem both individually or in association with other parameters during the metrical analysis of pattern bites. Moreover, a blind study analysing bite patterns on wax considering only inter-canines and inter-incisive width, was able to correctly identify only a varying percentage of the studied dogs (Toledo et al.).

Deutscher boxer breed evidenced a greater dispersion in its scores; the other breeds formed more compact groups. This high dispersion for Deutscher boxer breed could explain the similar measurements also found in the other two breeds (Table I). On the other hand, only the observations for German shepherd and Dalmatian breeds were different from one another for all variables. This may be due to significant differences in weights and size between them. In fact, Bernitz et al. (2012) support that small and large dogs can be differentiated by the intercanines width.

Nevertheless, despite the high dispersion found in the Deutscher boxer breed, the present study was able to classify and differentiate the three breeds using PCA (Fig. 1A). The quantification and use of a great number of dental morphometric variables and its analysis through multivariate analysis allowed a clear differentiation of the three studied breeds. For this reason, we should consider using, if possible, the greatest number of morphometric variables for the bite marks analysis. This is because, so far there is no official standard method established for the type, quality, and number of individual characteristics indicating that a bite mark reached a threshold of evidentiary value (Committee on Identifying the Needs of the Forensic Science Community et al., 2009).

Those variables would help making the identification easier, more precise, reliable, and unbiased, while pinpointing and identifying the biological profile of a potential aggressor dog through the comparison of bite marks left on the attack scene against the dental measures taken on the suspected dogs. This is true regardless of how low the variables' values are, and/or how essential these variables are to the variability and how these variables and others could play an important role in the final differentiation of a subject.

It is possible to affirm that both, females and males helped in differentiating between breeds for most of variables (Table I). However, although there were significant differences among breeds and sexes within breeds, only some variables and sexes allowed explaining this variability (Tables I, II, and III). For females, it can be inferred that the variables ManCW and MaxIW made it possible to differentiate among breeds (Table III). However, for males, the C-I-ManL variable helped in such a differentiation (Table II). This work confirms others findings (Carrasco et al., 2014) in which the sexual dimorphism and the variability among breeds, as well as some cephalic index-related measurements can be different for some breeds, depending on the head width, length, and shape. That is the reason why the analysis of bite marks can be a useful complementary resource as a breed identification method. 
While the head shape is considered the most important criterion for defining the standard of dog breeds, the rates and cranial indices are mostly used to identify their morphological types (Onar). Nonetheless, the dog's skull shows the biggest individual variation related to the shape and is measured for comparing different species (Carrasco et al.). This leads to a source of variation in sizes and teeth position, which also evidenced different appearances (Tedeschi-Oliveira et al.). Consequently, some systems of typological evaluation can be used for classify dogs breeds, not only measuring the head but also using, for example, the weight as a source of variation (Tedeschi-Oliveira et al.).

Compared to human bites, dog bites are usually different, often with some degree of distortion between the measurements obtained from both, the victim and the suspect. These distortions could hinder or even make it impossible to perform a physical analysis of the bite marks. Nonetheless, it is possible to get a match with a high degree of certainty or high probability (Bernitz et al.). This is feasible provided there are multiple points of concordance and zero discrepancies between the bite patterns found on the victim and the suspected dog's dentition. For this reason, the existing guide established by the forensic odontology community for such an analysis should be respected (Tedeschi-Oliveira et al.).

The macroscopic appearance from an acute animal bite reveals a combination of abrasions, contusions, and sometimes skins lacerations. All of them alter the physical appearance of the injury and its reaction (Toledo et al.). Consequently, a differentiation of various bites caused by dogs of the same breed is normally not possible. However, the analysis can help to identify the offender dog (De Munnynck \& Van de Voorde, 2002), moreover in bite marks analysis registered on inanimate objects, found in crime scene (bones, wood, wax as in this study, etc.).

The skin does not respond in a linear way to stress contributing to the possibility of distortion, affecting the identification of a suspect (Committee on Identifying the Needs of the Forensic Science Community et al.). Bite mark analysis in inanimate objects seems to offer more reliability than in the skin, and numerous papers, technical notes, and case reports have addressed different procedures to identify a perpetrator in the forensic arenas (Rollins \& Spencer, 1995; Rivera-Mendoza et al., 2018). Besides, numerous articles in taphonomic context have used bite marks (tooth marks) analysis registered on bone rests trying to establish or distinguishing the identity and number of carnivore taxa on bone assemblages from early archaeological sites (Dominguez-Rodrigo \& Piqueras, 2003; Delaney-Rivera et al., 2009), among others.
Nonetheless, the bite marks analysis must be used with extreme caution as an identification method. This is because many factors can influence the bite mark characteristics. Some of them depend on the offending agent (human or animals), bitten substrate (living or inanimate objects) (Tarvadi et al.). It can also play an important role the complex elastic characteristics of the skin, its response to the effects of pressure, the presence of multiple overlapping injuries, cutaneous continuity, subcutaneous attachment disruptions (Garamendi \& López Alcaraz, 2012), anatomical locations (arms, breast, etc.), and the dynamics of the biting, among others (Tarvadi et al.). In addition, one must consider that dogs are scavengers so it is possible to find bite marks on bone rests resulting from the carrion-eating process.

Although the court of law can accept the bite marks analysis, scientific reliability is still up for debate (Kashyap et al., 2015; Tarvadi et al.). However, Rivera-Mendoza et $a l$. found the most varied range of bitten substances, all of them belonging to sentenced cases, and many potentially treatable as legal precedents. As also described by Murmann (2006), this allows considering valid the analysis of bite marks on inanimate objects (e.g. wax) or on bones due to extreme hardness, low grade of deformation and degradation after a bite mark. In this perspective, these substrates could be consider reliable to assign a taxonomic value to bite marks.

Some authors like Garamendi \& López Alcaraz recommend taking dental impressions as comparative means between the suspect animals and the bite marks found on the scene. They also suggested that bite marks could help tracing some distinctive characteristics of the animal's dentition (rotation, misplacement, or lack of dental pieces). However, recent studies alert about the use of these bite marks for the identification based on specific characteristics of the dentition. Therefore, for a better identification, those morphometric studies could be, and in most of the cases have to be, complemented by morphological studies (Toledo et al.). The bite marks analysis usually combines metric and non-metric pattern bites found on both the victim and the potential biter. The metric analysis incorporates measures to its analysis while the non-metric incorporates analyses patterns (Tarvadi et al.).

It is also worth noting that dogs differ more in skull size than any other mammalian species (Carrasco et al.), and both skull shape and size have been suggested as sources of variation in the size and position of the teeth. On the one hand, due to the enormous variability among the dog breeds, it is recommended to classify the dogs according to different sources of variation like typological 
evaluation systems (e.g., weight) (Tedeschi-Oliveira et al.), and not only on the head shape (Morgan \& Palmer, 2007). On the other hand, in different dog breeds the masticatory force is associated with the weight, and excitement of the biting process. Several authors indicate that the force of biting dogs varies by breed: 31 to $3179 \mathrm{kPa}$ in trained attack dogs (Morgan \& Palmer), and more than $3102 \mathrm{kPa}$ in large dog breeds (Dehghani et al., 2016; O'Brien et $a l$. .). This would result in more severe injuries rather than slight (Dehghani et al.). The pressures generated from some dog bites can fracture bones depending on the victim, the dog breed, and the bitten anatomic region (O'Brien et $a l$.). Moreover, certain breeds can also create crush injuries due to the high pressures produced during the bite $(310-31790 \mathrm{KPa})$.

Some details to consider while collecting the evidence (bite marks) or making the recordings are the experience of the people sampling and measuring the characteristics of the materials used, the environmental conditions, as well as any factor that could alter the sample. According to Hernández-Carrasco et al. (2016) it is important to train veterinarians in order to create accurate registers, in a safe and reliable way. In addition it is recommended to sedate the subject during analytical procedures. This should be performed following security standards and rules established to protect either the sample than and the handler who might be injured during the sampling.

\section{CONCLUSIONS}

To achieve a good differentiation and classification among breeds, it is important to consider a great number of morphometric dental variables to be analysed with a powerful multivariate analysis tool such as PCA. Furthermore, the PCA models allow classifying, identifying, separating, and graphically showing the relationship among the variables. This made it possible to differentiate between breeds and sexes. Due to the extensive range of dog breeds around the world, this kind of multivariate analysis could help determining the dog's weight and size, narrowing down to an approximate number of offending dogs, focussing on a certain kind of dog breed, and ideally, identifying any suspect dog.

The study of animal bite mark evidence found on an attack scene is in fact a multidisciplinary exercise. Thus, it must be complemented with the study of other marks found on the victim, foodstuffs and inanimate objects (saliva, blood, fibbers, etc.), and on the suspect (gastric contents, stools, nails, etc.).
Given the increase in dog-bite related injuries and fatalities, it is necessary to expand the number of bite marks studies, both morphometric and morphological. Besides, new protocols have to be proposed, or the ones used for humans have to be adapted. They must consider outdoor, indoor, mixed or aquatic scenes, substrates (biological, inert), the moment when the mark was left (pre- or post-mortem), adjusting their photo setting procedures, collection, preservation, and shipment to the laboratory.

\section{ACKNOWLEDGEMENTS}

The authors wish to thank to the Doctoral Program in Forensic Science of the University of Alcalá (Madrid, Spain), and to the Asociación Iberoamericana de Medicina y Ciencias Veterinarias Forenses AG for the constant support.

TOLEDO-GONZÁLEZ, V.A.; ORTEGA-OJEDA, F. E.; FONSECA, G. M.; GARCÍA-RUIZ, C. \& PÉREZ-LLORET, P. Análisis de patrones de huellas de mordedura producidos por perros domésticos (Canis lupus familiaris) utilizando registros en cera dental. Int. J. Morphol., 37(2):885-893, 2019.

RESUMEN: Las mordeduras de perros son un conocido problema de salud pública que involucra traumas físicos, mentales y emocionales. En la faz forense, se ha establecido que características morfológicas, así como las medidas intercanina e interincisiva, permitirían una identificación taxonómica y especifica del animal involucrado. El objetivo fue diferenciar e identificar el perfil biológico de un potencial perro agresor analizando ocho patrones morfológicos de mordeduras pertenecientes a tres diferentes razas caninas. Los datos fueron analizados considerando tres categorías: a) razas; b) sexo entre razas; y c) sexo en cada raza. Se observaron diferencias entre las variables $(\mathrm{p} \leq 0,05)$, pero sólo la distancia máxima entre caninos maxilares (MaxCW), permitió una diferenciación entre razas. Las otras variables permitieron una diferenciación entre dos razas o de una raza sobre las otras. El análisis de componentes principales (PCA) permitió visualizar el grado de dispersión y la relación entre las puntuaciones (dentro y entre razas). Se observaron tres grupos (razas) bien definidos y separados con diferentes grados de dispersión dentro y entre razas. La variable más importante para tal diferenciación fue la MaxCW. Al considerar sexo (machos) entre razas, se encontró diferencia estadísticamente significativa, pero sólo la medida del diastema localizado entre el tercer incisivo y canino izquierdo mandibulares (C-I-ManL) permitió la diferenciación entre razas. Para hembras, sólo la MaxCW permitió una diferenciación entre razas. El análisis multivariante permitió, con un intervalo de confianza del $95 \%$, diferenciar raza y sexo. El modelo PCA permitió además clasificar, identificar, separar y mostrar gráficamente la relación entre las variables. Esto posibilitó diferenciar entre razas y sexos. Debido a la gran variedad de razas de perros en el mundo, este análisis multivariado permitiría estimar peso y tamaño del animal, indicando un número aproximado de perros atacantes, centrándose en ciertos tipos de raza, y localizar a cualquier cánido sospechoso.

PALABRAS ClAVE: Mordeduras de perros; Ciencia forense; Odontología forense; Veterinaria forense. 


\section{REFERENCES}

Abuabara, A. A review of facial injuries due to dog bites. Med. Oral Patol. Oral Cir. Bucal, 11(4):E348-50, 2006.

Alabi, O.; Nguku, P.; Chukwukere, S.; Gaddo, A.; Nsubuga, P. \& Umoh, J. Profile of dog bite victims in Jos Plateau State, Nigeria: a review of dog bite records (2006-2008). Pan. Afr. Med. J., 18(Suppl. 1):12, 2014.

American Board of Forensic Odontology (ABFO). Standards and Guidelines for Evaluating Bitemarks, Revised 2-19-2018. American Board of Forensic Odontology, 2018. Available from: http://abfo.org/ wp-content/uploads/2012/08/ABFO-Standards-Guidelines-forEvaluating-Bitemarks-Feb-2018.pdf

Bernitz, H.; Bernitz, Z.; Steenkamp, G.; Blumenthal, R. \& Stols, G. The individualisation of a dog bite mark: a case study highlighting the bite mark analysis, with emphasis on differences between dog and human bite marks. Int. J. Legal Med., 126(3):441-6, 2012.

Byard, R. W. Domestic dogs (Canis lupus familiaris) and forensic practice. Forensic Sci. Med. Pathol., 12(3):241-2, 2016.

Carrasco, J. J.; Georgevsky, D.; Valenzuela, M. \& McGreevy, P. D. A pilot study of sexual dimorphism in the head morphology of domestic dogs. J. Vet. Behav., 9(1):43-6, 2014.

Chhabra, S.; Chhabra, N. \& Gaba, S. Maxillofacial injuries due to animal bites. J. Maxillofac. Oral Surg., 14(2):142-53, 2013.

Colard, T.; Delannoy, Y.; Naji, S.; Gosset, D.; Hartnett, K. \& Bécart, A. Specific patterns of canine scavenging in indoor settings. J. Forensic Sci., 60(2):495-500, 2015.

Committee on Identifying the Needs of the Forensic Science Community; Committee on Science, Technology \& Law Policy and Global Affairs, Committee on Applied and Theoretical Statistics, Division on Engineering and Physical Sciences. National Research Council of the National Academies. Strengthening Forensic Science in the United States: A Path Forward. Washington D. C., The National Academies Press, 2009.

Dago Morales, A.; Cavado Osorio, A.; Fernández Fernández, R. \& Linchenat Dennes, E. Desarrollo de un modelo SIMCA para la clasificación de kerosinas mediante el empleo de la espectroscopía infrarroja. Quim. Nova, 31(6):1573-6, 2008.

De Munnynck, K. \& Van de Voorde, W. Forensic approach of fatal dog attacks: a case report and literature review. Int. J. Legal Med., 116(5):295-300, 2002.

Dehghani, R.; Sharif, A.; Madani, M.; Kashani, H. H. \& Sharif, M. R. Factors influencing animal bites in Iran: a descriptive study. Osong Public Health Res. Perspect., 7(4):273-7, 2016.

Delaney-Rivera, C.; Plummer, T. W.; Hodgson, J. A.; Forrest, F.; Hertel, F. \& Oliver, J. S. Pits and pitfalls: taxonomic variability and patterning in tooth mark dimensions. J. Archaeol. Sci., 36(11):2597-608, 2009.

Domínguez-Rodrigo, M. \& Piqueras, A. The use of tooth pits to identify carnivore taxa in tooth-marked archaeofaunas and their relevance to reconstruct hominid carcass processing behaviours. J. Archaeol. Sci., 30(11):1385-91, 2003.

Fonseca, G. M.; Mora, E.; Lucena, J. \& Cantín, M. Forensic studies of dog attacks on humans: a focus on bite mark analysis. Res. Rep. Forensic Med. Sci., 5:39-51, 2015.

Garamendi, P. M. \& López Alcaraz, M. Ataque mortal por perros de raza rottweiller a una mujer adulta: posible ataque en manada y antropofagia postmortal. Revisión y análisis de un caso de autopsia médico legal. Cuad. Med. Forense, 18(2):71-80, 2012.

Hernández-Carrasco, M.; Pisani, J. M. A.; Scarso Giaconi, F. \& Fonseca, G. M. Indoor postmortem mutilation by dogs: Confusion, contradictions, and needs from the perspective of the forensic veterinarian medicine. J. Vet. Behav. Clin. Appl. Res., 15:56-60, 2016.

Karbeyaz, K. \& Ayranci, U. A forensic and medical evaluation of dog bites in a province of Western Turkey. J. Forensic Sci., 59(2):505-9, 2014.
Kashyap, B.; Anand, S.; Reddy, S.; Sahukar, S. B.; Supriya, N. \& Pasupuleti, S. Comparison of the bite mark pattern and intercanine distance between humans and dogs. J. Forensic Dent. Sci., 7(3):175-9, 2015.

Morgan, M. \& Palmer, J. Dog bites. B. M. J., 334(7590):413-7, 2007.

Muñoz Leyva, F. Mordedura canina. Univ. Med., 53(1):43-55, 2011.

O'Brien, D. C.; Andre, T. B.; Robinson, A. D.; Squires, L. D. \& Tollefson, T. T. Dog bites of the head and neck: an evaluation of a common pediatric trauma and associated treatment. Am. J. Otolaryngol., 36(1):32-8, 2015.

Onar, V. A morphometric study on the skull of the German shepherd dog (Alsatian). Anat. Histol. Embryol., 28(4):253-6, 1999.

Rivera-Mendoza, F.; Martín-de-Las-Heras, S.; Navarro-Cáceres, P. \& Fonseca, G. M. Bite mark analysis in foodstuffs and inanimate objects and the underlying proofs for validity and judicial acceptance. $J$. Forensic Sci., 63(2):449-59, 2018.

Rollins, C. E. \& Spencer, D. E. A fatality and the American mountain lion: bite mark analysis and profile of the offending lion. J. Forensic Sci., 40(3):486-9, 1995.

Rothe, K.; Tsokos, M. \& Handrick, W. Animal and human bite wounds. Dtsch. Ärztebl. Int., 112(25):433-43, 2015.

Skavic, P.; Sprem, N. \& Kostelic, A. Fatal injury caused by a ram (Ovis aries) attack. J. Forensic Sci., 60(5):1380-2, 2015.

Tarvadi, P.; Manipady, S. \& Shetty, M. Intercanine distance and bite marks analysis using metric method. Egypt. J. Forensic Sci., 6(4):445-8, 2016.

Tedeschi-Oliveira, S. V.; Trigueiro, M.; Oliveira, R. N. \& Melani, R. F. Intercanine distance in the analysis of bite marks: a comparison of human and domestic dog dental arches. J. Forensic Odontostomatol., 29(1):30-6, 2011.

Toledo, G. V.; Ibarra, M. L.; Rojas, E. V.; Ciocca, G. L.; Rocha, D. N. \& Jara, V. G. Preliminary study of bite patterns according to skull shape, by morphological and morphometric analysis of dental semi arcs of domestic dog (Canis familiaris) for identification. Int. J. Morphol., 30(1):222-9, 2012.

Tsokos, M.; Byard, R. W. \& Püschel, K. Extensive and mutilating craniofacial trauma involving defleshing and decapitation: unusual features of fatal dog attacks in the young. Am. J. Forensic Med. Pathol., 28(2):131-6, 2007.

Corresponding author:
Dr. Gabriel M. Fonseca

Centro de Investigación en Odontología Legal y Forense

(CIO)

Facultad de Odontología

Universidad de La Frontera

Francisco Salazar 01145, Pabellón L

Temuco

CHILE

E-mail: gabriel.fonseca@ufrontera.cl

Received: 02-12-2018

Accepted: 08-02-2019 